\begin{tabular}{|l|l|l||}
\hline \multicolumn{2}{|c|}{ PublisherInfo } \\
\hline \hline PublisherName & $:$ & BioMed Central \\
\hline \hline PublisherLocation & $:$ & London \\
\hline \hline PublisherImprintName & $:$ & BioMed Central \\
\hline \hline
\end{tabular}

\title{
'No' to starch in sepsis
}

\begin{tabular}{|l|l|l||}
\hline \multicolumn{2}{|c||}{ ArticleInfo } \\
\hline \hline ArticleID & $:$ & 4303 \\
\hline \hline ArticleDOI & $:$ & $10.1186 /$ ccf-2001-73255 \\
\hline \hline ArticleCitationID & $:$ & 73255 \\
\hline \hline ArticleSequenceNumber & $:$ & 14 \\
\hline \hline ArticleCategory & $:$ & Paper Report \\
\hline \hline ArticleFirstPage & $:$ & 1 \\
\hline \hline ArticleLastPage & $:$ & 3 \\
\hline \hline & & RegistrationDate : 2001-12-4 \\
ArticleHistory & $:$ & Received \\
\hline ArticleCopyright & $:$ 2001-4-30 \\
\hline \hline ArticleGrants & $:$ & OnlineDate \\
\hline \hline ArticleContext & $:$ & 1305455 \\
\hline \hline
\end{tabular}


Aff1 St George's Hospital, London, UK

\section{Keywords}

Acute renal failure, colloid fluid resuscitation, gelatins, sepsis, starches

\section{Context}

There has been, and indeed remains, much debate as to the optimal fluid management of critically ill patients, especially those with sepsis, both in terms of the dose and the composition of the fluids employed. What little evidence exists is mostly contradictory. There is good evidence that packed red blood cells are detrimental (see Additional information [1,2]), although the mechanism is disputed. Aside from this, the colloid versus crystalloid debate continues. This is complicated by the variety of colloids available with comparisons between gelatins, starches, and albumin impossible to make. This study aimed to and succeeded in answering the question, "Does hydroxyethylstarch cause renal failure in septic patients?" The main impetus for this trial was a study from braindead organ donors where a higher incidence of renal failure was noted in recipients of organs from subjects who had received hydroxyethylstarch (see Additional information [3]).

\section{Significant findings}

Acute renal failure (ARF) defined as the need for renal replacement therapy or a twofold increase in serum creatinine concentration over the value at study entry, was more common in the hydroxyethylstarch group (odds ratio 2.32). Multivariate analysis also found mechanical ventilation and absence of fluid loading prior to study entry to be independent risk factors for ARF. Despite this, the length of intensive care unit (ICU) stay and ICU mortality were the same in both groups. The authors concluded that since the groups were well matched, the differences observed were due to the hydroxyethylstarch. They suggested that this particular starch be avoided in patients at risk of renal failure, and that other starches should be used with caution.

\section{Comments}


This trial represents a compelling argument that, in the absence of any benefit and in the presence of a growing body of evidence for significant harm, starches be abandoned as a fluid therapy. As is often the case in intensive care clinical trials, a number of methodological criticisms can be made against this trial. In particular, the method employed to judge the adequacy of volume resuscitation was poor, there was a large (but not statistically significant) difference in the volume of colloid given to the two groups, and the criteria for initiation of renal replacement therapy was not stated. However, the authors justify and discuss most of the shortcomings of their design and their findings and should be applauded for their efforts.

\section{Methods}

Multicentre randomized single blind study.

\section{Additional information}

1. Hebert PC, Wells G, Blajchman MA, Marshall J, Martin C, Pagliarello G, Tweeddale M, Schweitzer I, Yetisir E: A multicenter, randomized, controlled clinical trial of transfusion requirements in critical care. Transfusion requirements in critical care investigators, Canadian critical care trials group. $N$ Engl J Med 1999, 340:409-417.

2. Hebert PC, Yetisir E, Martin C, Blajchman MA, Wells G, Marshall J, Tweeddale M, Pagliarello $\mathrm{G}$, Schweitzer I: Is a low transfusion threshold safe in critically ill patients with cardiovascular diseases? Crit Care Med 2001, 29:227-234.

3. Cittanova ML, LeBlanc I, Legendre C, Mouquet C, Riou C, Couriat P: Effect of hydroxyethylstarch in brain-dead kidney donors on renal function in kidney-transplant recipients. Lancet 1996, 348:1620-1622.

\section{References}

1. Schortgen F, Lacherade JC, Bruneel F, Cattaneo I, Hemery F, Lemaire F, Brochard L: Effects of hydroxyethylstarch and gelatin on renal function in severe sepsis: a multicentre randomised study. Lancet. 2001, 357: 911-916. 